\title{
Oral acyclovir in acute herpes zoster
}

\author{
M W McKENDRICK, J I McGILL, J E WHITE, M J WOOD
}

\begin{abstract}
Oral acyclovir at a dose of $\mathbf{8 0 0} \mathbf{~ m g}$ five times daily for seven days was compared with placebo in a randomised double blind trial conducted at three centres in the United Kingdom. The study group comprised 205 elderly immune competent patients suffering from herpes zoster who were entered within 72 hours of the onset of rash. Acyclovir significantly reduced the times to arrest of new lesion formation ( $p=0.005)$, loss of vesicles $(p<0.001)$, and full crusting $(p=0.02)$ in those patients entered within 48 hours of the onset of rash. In addition, there was a significant reduction in pain during treatment with acyclovir as compared with placebo $(p=0.008)$. Of the patients with severe pain on entry, $40 \%(10 / 25)$ of those treated with acyclovir had no or only mild pain at the end of treatment, whereas in the placebo group all had residual moderate or severe pain $(\mathbf{p}<0.001)$. No clinically important adverse effects of acyclovir were reported.

Oral acyclovir may modify acute herpes zoster and reduce pain.
\end{abstract}

\section{Introduction}

Herpes zoster is a common disease occurring predominantly in the elderly and is often associated with severe pain in the acute phase and with profound and protracted postherpetic neuralgia. Antiviral treatment offers a logical approach to reducing pain by inhibiting viral replication and hence reducing tissue damage. Double blind

\footnotetext{
Department of Medicine and Communicable Diseases, Lodge Moor Hospital, Sheffield 10

M W MCKENDRICK, MB, MRCP, consultant physician

Southampton Eye Hospital, Southampton

J I MCGILL, DPHIL, FRCS, consultant ophthalmic surgeon

Royal South Hants Hospital, Southampton

J E WHITE, MD, FRCP, consultant dermatologist

Department of Communicable and Tropical Diseases, East Birmingham Hospital, Bordesley Green East, Birmingham

M J WOOD, BM, MRCP, consultant physician

Correspondence to: Dr McKendrick.
}

placebo controlled studies have shown acyclovir at doses of $5 \mathrm{mg} / \mathrm{kg}$ or greater eight hourly intravenously for five days to modify the development of rash and reduce acute pain ${ }^{1.3}$ and topically applied acyclovir to control ocular manifestations. ${ }^{+}$Oral treatment, however, is more practical for herpes zoster, as most patients do not require hospital management. About $15-20 \%$ of acyclovir taken by mouth is absorbed. Peterslund et al using an oral dose of $400 \mathrm{mg}$ five times daily for five days did not find significant differences compared with intravenous acyclovir $(5 \mathrm{mg} / \mathrm{kg}$ eight hourly for five days) in the treatment of herpes zoster, though the number of patients in their study was small and only patients with a history of rash and prodrome of less than 96 hours were included. ${ }^{5} \mathrm{~A}$ double blind placebo controlled study using the same oral dosing regimen of acyclovir showed a significant reduction in days of new lesion development within the affected dermatome in the acyclovir group, though differences in other characteristics did not achieve statistical significance. ${ }^{6}$ Acyclovir $800 \mathrm{mg}$ four hourly by mouth has been shown to give mean steady state peak and trough concentrations of 7.5 and $4.5 \mu \mathrm{mol} / 1(0.17$ and $0.10 \mathrm{mg} / 100 \mathrm{ml})$ respectively (unpublished findings), which are in excess of the median effective dose $\left(\mathrm{ED}_{50}\right)$ of most strains of varicella zoster virus and may be a more rational dosage regimen for herpes zoster infections.

Double blind placebo controlled studies of $800 \mathrm{mg}$ acyclovir five times daily for seven days were therefore initiated at three centres within the United Kingdom (Sheffield, Birmingham, and Southampton) using a common protocol. The trial was designed to determine the efficacy of oral acyclovir in the acute stage of herpes zoster.

\section{Patients and methods}

We studied immune competent patients of either sex, aged 60 or over, presenting with herpes zoster. Patients were excluded if the rash was of greater than 72 hours' duration, if there was known renal insufficiency, or if they had received other antiviral treatment. Approval by the ethical committee was obtained and all patients gave informed consent.

The trial was domiciliary based and dependent on referral by general practitioners. Entry was initiated by the research nurse after initial assessment and treatment started within four hours of referral. An early examination of the patient was made by the principal clinical investigator if there was any doubt about the diagnosis or suitability of the patient for the study. The clinical care of each patient remained with the general practitioner unless admission to hospital was necessary. Patients with ocular 
manifestations were referred for ophthalmic care, as topical ocular acyclovir was not a contraindication to continuing the study.

The trial was double blind and randomised. Patients received $800 \mathrm{mg}$ acyclovir or placebo four hourly, omitting the dose in the middle of the night (five doses in 24 hours), for seven days. The tablets were packaged and labelled at the Wellcome Foundation according to a prearranged system of random allocation prepared by the statistical department of the Wellcome Research Laboratories in Beckenham.

TABLE I-Characteristics of patients

\begin{tabular}{|c|c|c|c|}
\hline & & $\begin{array}{l}\text { Acyclovir group } \\
\quad(n=100)\end{array}$ & $\begin{array}{l}\text { Placebo group } \\
\quad(n=105)\end{array}$ \\
\hline Sex & $\left\{\begin{array}{l}\text { Male } \\
\text { Female }\end{array}\right.$ & $\begin{array}{l}41 \\
59\end{array}$ & $\begin{array}{l}46 \\
59\end{array}$ \\
\hline Age (years) & $\left\{\begin{array}{l}\text { Mean } \\
\text { Range }\end{array}\right.$ & $\begin{array}{l}72 \cdot 9 \\
60-89\end{array}$ & $\begin{array}{l}70 \cdot 8 \\
60-92\end{array}$ \\
\hline Duration of prodrome (hours) & $\left\{\begin{array}{l}<48 \\
48-96 \\
>96\end{array}\right.$ & $\begin{array}{l}37 \\
26 \\
37\end{array}$ & $\begin{array}{l}33 \\
29 \\
43\end{array}$ \\
\hline Duration of rash (hours) ${ }^{\star}$ & $\left\{\begin{array}{l}<24 \\
24-47 \\
48-72\end{array}\right.$ & $\begin{array}{l}30 \\
36 \\
32\end{array}$ & $\begin{array}{l}35 \\
35 \\
35\end{array}$ \\
\hline Extent of rash (lesion count) $†$ & $\left\{\begin{array}{l}<50 \\
>50\end{array}\right.$ & $\begin{array}{l}62 \\
38\end{array}$ & $\begin{array}{l}67 \\
37\end{array}$ \\
\hline Site & $\left\{\begin{array}{l}\text { Ophthalmic } \\
\text { Other }\end{array}\right.$ & $\begin{array}{l}21 \\
79\end{array}$ & $\begin{array}{l}32 \\
73\end{array}$ \\
\hline Pain scoreł & $\left\{\begin{array}{l}0 \\
1 \\
2 \\
3\end{array}\right.$ & $\begin{array}{r}9 \\
21 \\
44 \\
26\end{array}$ & $\begin{array}{r}5 \\
26 \\
41 \\
31\end{array}$ \\
\hline
\end{tabular}

*Two values missing in acyclovir group.

fOne value missing in placebo group.

$\ddagger$ Two values missing in placebo group. assessment being made without access to previous records. Blood for biochemical and haematological screening was taken before treatment and on day 2 or 3, and in addition on day 6 or 7 at two of the centres.

The times to observed changes in characteristics of the rash were analysed using the Mantel-Cox (log rank) test. Survival curves of rash progression were estimated by the Kaplan-Meier technique. Variables of rash progression were analysed using one tailed tests. The changes in pain severity scores between day 0 and day 6 and the distribution of the pain scores on day 6 were analysed using Mann-Whitney $U$ tests.

\section{Results}

Two hundred and nine patients entered the study and were randomised to the treatment groups. Four were subsequently withdrawn for the following reasons. One patient (case 12; acyclovir, Birmingham) suffered vomiting attacks after both the first and second doses on day 0 ; in case 14 (placebo, Birmingham) the patient's condition worsened, requiring admission for intravenous acyclovir after three days; in case 28 (acyclovir, Birmingham) there was a violation of protocol (at one stage 21 tablets had been taken in less than 24 hours); and one patient (case 89; acyclovir, Sheffield) was diagnosed as not suffering from zoster. Thus 205 subjects were available for analysis, of whom 96 were from Sheffield, 62 from Birmingham, and 47 from Southampton. The groups were comparable for sex and age; duration of prodrome; severity, distribution, and duration of rash; and severity of pain (table I).

\section{PROGRESSION OF RASH}

Acyclovir was associated with significantly accelerated healing when treatment was started within 48 hours of the onset of rash (table II). Treatment begun between 48 and 72 hours resulted in no significant differences between the two treatment groups, though there were trends in favour of acyclovir (table II). Small differences in numbers of patients

TABLE II-Rash progression in days for all patients entered up to 47 and 48 to 72 hours after onset of rash. Mean values expressed with standard error $(S E)$ in parentheses

\begin{tabular}{|c|c|c|c|c|c|c|c|c|}
\hline \multirow[b]{2}{*}{ Stage of rash } & \multirow[b]{2}{*}{ Severity of rash } & \multicolumn{3}{|c|}{ Acyclovir group } & \multicolumn{3}{|c|}{ Placebo group } & \multirow[b]{2}{*}{$\begin{array}{c}\text { p Value } \\
(\log \text { rank })\end{array}$} \\
\hline & & $\begin{array}{l}\text { Mean } \\
\text { (days) }\end{array}$ & $\begin{array}{c}\text { Median } \\
\text { (days) }\end{array}$ & $\begin{array}{l}\text { No } \\
\text { studied }\end{array}$ & $\begin{array}{l}\text { Mean } \\
\text { (days) }\end{array}$ & $\begin{array}{c}\text { Median } \\
\text { (days) }\end{array}$ & $\begin{array}{l}\text { No } \\
\text { studied }\end{array}$ & \\
\hline \multicolumn{9}{|c|}{ Patients entered up to 47 hours after onset } \\
\hline Last day of new lesion formation & $\left\{\begin{array}{l}\text { All } \\
\text { Moderate/severe }\end{array}\right.$ & $\begin{array}{l}1.7(0.15) \\
1.6(0.18)\end{array}$ & $\begin{array}{l}2 \\
2\end{array}$ & $\begin{array}{l}62^{\star} \\
44\end{array}$ & $\begin{array}{l}2 \cdot 2(0 \cdot 21) \\
2 \cdot 4(0 \cdot 26)\end{array}$ & $\begin{array}{l}2 \\
2\end{array}$ & $\begin{array}{l}69+ \\
41\end{array}$ & $\begin{array}{l}0.005 \\
0.003\end{array}$ \\
\hline Loss of vesicles & $\left\{\begin{array}{l}\text { All } \\
\text { Moderate/severe }\end{array}\right.$ & $\begin{array}{l}6 \cdot 4(0 \cdot 70) \\
7 \cdot 0(0 \cdot 80)\end{array}$ & $\begin{array}{l}5 \\
6\end{array}$ & $\begin{array}{l}65 \dagger \\
45\end{array}$ & $\begin{array}{l}8 \cdot 2(0.52) \\
8 \cdot 7(0.64)\end{array}$ & $\begin{array}{l}8 \\
9\end{array}$ & $\begin{array}{l}70 \\
41\end{array}$ & $\begin{array}{r}<0.001 \\
0.003\end{array}$ \\
\hline Full crusting & $\left\{\begin{array}{l}\text { All } \\
\text { Moderate/severe }\end{array}\right.$ & $\begin{array}{l}7.8(0.80) \\
8.6(0.97)\end{array}$ & $\begin{array}{l}7 \\
8\end{array}$ & $\begin{array}{l}65 t \\
45\end{array}$ & $\begin{array}{l}10 \cdot 0(0 \cdot 73) \\
11 \cdot 3(1.06)\end{array}$ & $\begin{array}{l}10 \\
10\end{array}$ & $\begin{array}{l}70 \\
41\end{array}$ & $\begin{array}{l}0.02 \\
0.04\end{array}$ \\
\hline \multicolumn{9}{|c|}{ Patients entered 48 to 72 hours after onset } \\
\hline Last day of new lesion formation & $\left\{\begin{array}{l}\text { All } \\
\text { Moderate/severe }\end{array}\right.$ & $\begin{array}{l}0.9(0.13) \\
0.8(0.13)\end{array}$ & $\begin{array}{l}1 \\
1\end{array}$ & $\begin{array}{l}31 \dagger \\
22\end{array}$ & $\begin{array}{l}1 \cdot 3(0 \cdot 26) \\
1 \cdot 2(0 \cdot 31)\end{array}$ & $\begin{array}{l}1 \\
1\end{array}$ & $\begin{array}{l}35 \\
23\end{array}$ & $\begin{array}{l}0 \cdot 12 \\
0 \cdot 12\end{array}$ \\
\hline Loss of vesicles & $\left\{\begin{array}{l}\text { All } \\
\text { Moderate/severe }\end{array}\right.$ & $\begin{array}{l}5.2(0.59) \\
5.6(0.68)\end{array}$ & $\begin{array}{l}5 \\
5\end{array}$ & $\begin{array}{l}30 \ddagger \\
22\end{array}$ & $\begin{array}{l}5.5(0.72) \\
6.6(0.85)\end{array}$ & $\begin{array}{l}5 \\
6\end{array}$ & $\begin{array}{l}35 \\
23\end{array}$ & $\begin{array}{l}0 \cdot 30 \\
0 \cdot 17\end{array}$ \\
\hline Full crusting & $\left\{\begin{array}{l}\text { All } \\
\text { Moderate/severe }\end{array}\right.$ & $\begin{array}{l}6.2(0.68) \\
6.9(0.81)\end{array}$ & $\begin{array}{l}5 \\
6\end{array}$ & $\begin{array}{l}31 \dagger \\
22\end{array}$ & $\begin{array}{l}7.6(0.98) \\
8.0(0.95)\end{array}$ & $\begin{array}{l}6 \\
8\end{array}$ & $\begin{array}{l}35 \\
23\end{array}$ & $\begin{array}{l}0 \cdot 16 \\
0 \cdot 25\end{array}$ \\
\hline
\end{tabular}

${ }^{\star}$ Four values missing.

tOne value missing.

$\ddagger$ Two values missing.

Patients were assessed by the research nurse on entry (day 0 ), daily to day 7 , and then every other day to day 13 or until all lesions had crusted. Further follow up was continued at weekly intervals until day 28 and then monthly for a further five months or until all pain had stopped, when patients were discharged. On entry the patient's age, sex, duration of prodrome, and duration of rash were noted. The extent and distribution of the rash were scored according to the number of discrete lesions in the dermatome $(0=$ none, $1=<25,2=26-50,3=51-100,4=>100)$ and details of the appearance of the lesions were recorded (macule/papule, vesicle/pustule, ulceration, or crust). Scores of 3 and 4 were regarded as severe and 2 moderate. The severity of pain was recorded by the patient on a linear visual analogue scale of $0-100 \%$ ranging from "none" to "very severe." For analysis this was converted to nil $=0,1-24 \%=1,25-75 \%=2$, and $76-100 \%=3$. Patients were also asked to give a pain score from 0 to 10 , each reflected occasional lack of data on specific observation. Analysis of rash progression in all patients who had herpes zoster affecting the ophthalmic division of the trigeminal nerve showed no apparent significant differences between acyclovir and placebo (table III). There were too few patients with ophthalmic zoster to stratify according to duration of rash before the start of treatment.

\section{ACUTE PAIN}

Analysis of average daily pain scores for change in pain from day 0 (baseline) to day 6 (last 24 hours of treatment) using the $0-3$ scoring system showed a highly significant reduction in the acyclovir group compared with 
placebo ( $p=0.008$ ) (table IV). Analysis using the $0-10$ scoring system also showed a significant reduction in the acyclovir treated group $(p=0.03)$. The figure plots the average daily pain scores for both groups during the acute phase of the study. Significance was maintained in the subgroups of patients with moderate or severe pain at entry.

Table $\mathrm{V}$ shows the distribution of pain scores at day 6 related to pain score on entry. Forty per cent of patients (10/25) with a score of 3 on entry who received acyclovir had a score of 0 or 1 at day 6 compared with none in the placebo group $(\mathrm{p}<0.001)$.

Adverse events were recorded in 12 patients in the acyclovir group and significant improvement has occurred during the treatment period. ${ }^{\prime}$ This might be explained on the basis that viral replication may persist beyond five days, and a seven day period of treatment was therefore used. An alternative explanation may be that acyclovir has some intrinsic analgesic properties.

In this study patients treated with acyclovir had significantly enhanced rates of resolution of rash and, more importantly by, a significant reduction in pain scores during the period of treatment. This was most noticeable in patients with a pain score of 3 at entry,

TABLE III-Rash progression in patients with ophthalmic zoster. Mean values expressed with SE in parentheses

\begin{tabular}{|c|c|c|c|c|c|c|c|}
\hline \multirow[b]{2}{*}{ Stage of rash } & \multicolumn{3}{|c|}{ Acyclovir group } & \multicolumn{3}{|c|}{ Placebo group } & \multirow[b]{2}{*}{$\begin{array}{c}\mathrm{p} \text { Value } \\
\text { (log rank) }\end{array}$} \\
\hline & $\begin{array}{l}\text { Mean } \\
\text { (days) }\end{array}$ & $\begin{array}{c}\text { Median } \\
\text { (days) }\end{array}$ & $\begin{array}{c}\text { No } \\
\text { studied }\end{array}$ & $\begin{array}{l}\text { Mean } \\
\text { (days) }\end{array}$ & $\begin{array}{c}\text { Median } \\
\text { (days) }\end{array}$ & $\begin{array}{c}\text { No } \\
\text { studied }\end{array}$ & \\
\hline Last new lesion & $2 \cdot 1(0.22)$ & 2 & $19^{\star}$ & $2.5(0.28)$ & 2 & 32 & $0 \cdot 10$ \\
\hline Loss of vesicles & $6.3(1.27)$ & 5 & $20+$ & $5.5(0.45)$ & 5 & 32 & 0.41 \\
\hline Full crusting & $7 \cdot 2(1 \cdot 28)$ & 6 & 21 & $7.0(0.53)$ & 7 & 32 & $0 \cdot 21$ \\
\hline
\end{tabular}

^Two values missing.

tOne value missing.

TABLE IV-Average changes in pain during treatment (day 6 to day 0 ). Mean values expressed with SE in parentheses

\begin{tabular}{|c|c|c|c|c|c|}
\hline & \multicolumn{2}{|c|}{ Acyclovir group } & \multicolumn{2}{|c|}{ Placebo group } & \multirow[b]{2}{*}{$\begin{array}{c}\text { p Value } \\
\text { (Mann-Whitney })\end{array}$} \\
\hline & $\begin{array}{l}\text { Mean } \\
\text { change }\end{array}$ & $\begin{array}{l}\text { No } \\
\text { studied }\end{array}$ & $\begin{array}{l}\text { Mean } \\
\text { change }\end{array}$ & $\begin{array}{l}\text { No } \\
\text { studied }\end{array}$ & \\
\hline All patients & $-0 \cdot 7(0 \cdot 1)$ & $97^{\star}$ & $-0.3(0.07)$ & $99 \$$ & 0.008 \\
\hline Patients with score of 2 or 3 on entry & $-0.9(0.12)$ & $68+$ & $-0.5(0.08)$ & $69^{\star}$ & 0.03 \\
\hline Patients with score of 3 on entry & $-1 \cdot 4(0 \cdot 2)$ & $25 \ddagger$ & $-0.6(0.09)$ & $30 \neq$ & 0.001 \\
\hline Patients with ophthalmic zoster & $-0.7(0.13)$ & $20 \ddagger$ & $-0 \cdot 3(0 \cdot 18)$ & $27 \%$ & $0 \cdot 14$ \\
\hline
\end{tabular}

TABLE V—Distribution of pain scores at day 6 related to pain score at entry

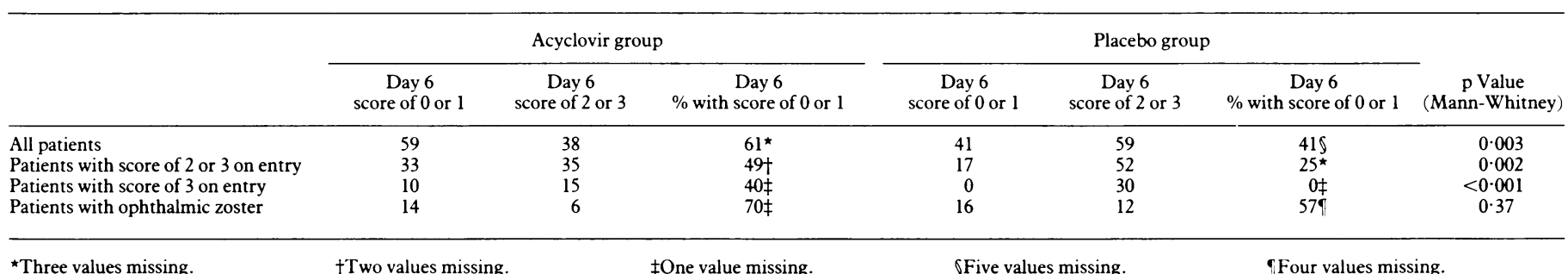

13 in the placebo group. These included 10 reports of gastrointestinal symptoms in the acyclovir group and nine in the placebo group and three neurological events (headache, tremor, giddiness) in the acyclovir group compared with eight in the placebo group (headache (two patients), hallucinations (one), shaking (one), giddiness (two), confusion (two)). Haematological and biochemical safety data showed no adverse effects of treatment.

\section{Discussion}

Intravenous acyclovir has been shown to have a significant effect on the development of rash and acute pain in herpes zoster. ${ }^{1.3}$ The oral route of administration is the most practical way to take acyclovir for most patients, and this study has attempted to define whether $800 \mathrm{mg}$ acyclovir five times daily for seven days is an effective regimen. Studies with lower doses $^{56}$ have not been associated with consistent benefit and the $800 \mathrm{mg}$ dose appears to be satisfactory from pharmacokinetic data (unpublished findings). Patients treated for five days have been noted in some instances to develop a post-treatment exacerbation of pain even though a
$40 \%$ of whom (10/25) had a score of 0 or 1 by the end of acyclovir treatment, compared with those who received placebo, all of whom still had a pain score of 2 or 3 at day 6 . Regression in pain, however, did not appear to continue after stopping acyclovir (figure). It would be interesting to know whether a longer course of treatment would provide better results or whether combination with steroids might be beneficial, as high dose prednisone has been reported to reduce pain. ${ }^{78}$ Whether postherpetic neuralgia will be modified by the regimen employed in this study is not yet known, though results should be available within 12 months.

It is essential that treatment for any self limiting disease should be started early to maximise the possibility of influencing the course of the illness. Patients with herpes zoster usually have evidence of a prodromal illness pointing to viral activity before the onset of the rash. In this study $80(39 \%)$ of the patients entered had a prodrome of greater than 96 hours and only $70(34 \%)$ had a prodrome of less than 48 hours. This is one of the main differences from the study by Peterslund $e t a l$, who included only patients with combined rash and prodrome of less than 96 hours; in addition, there was no placebo group in their study. Stratification of patients in our study illustrates the importance of early treatment. 


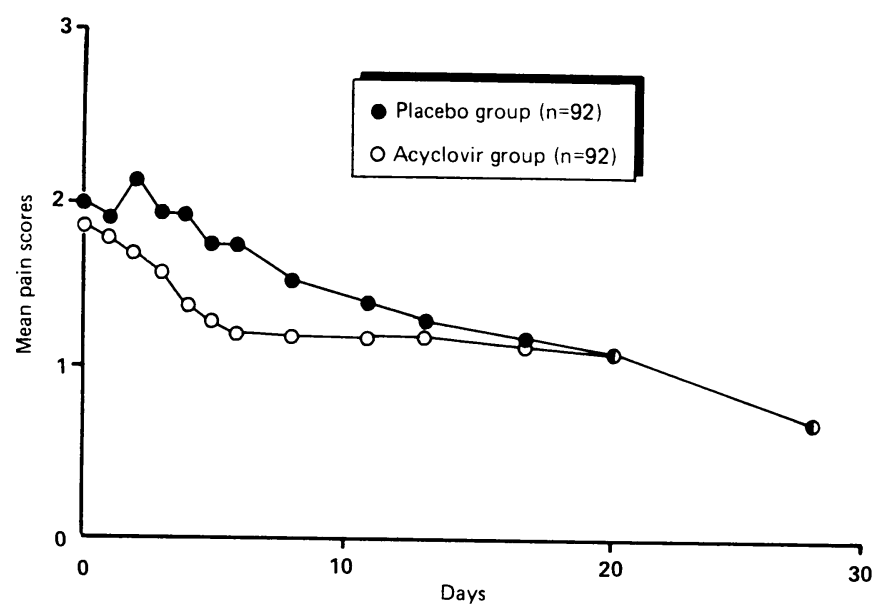

Plot of average daily pain scores (0-3 scale) in the two treatment groups. (Number of patients in each group were those with complete set of observations.)

The single dermatome most commonly affected in herpes zoster is the ophthalmic division of the trigeminal nerve. Though trends in favour of the treatment group were seen with regard to reduction in pain (day 6 to day 0 ), the changes did not reach statistical significance $(p=0 \cdot 14)$. This may relate to the fact that the number of patients with ophthalmic zoster was relatively small-53 (21 acyclovir, 32 placebo)-and 24 (45\%) of these had a rash of 48 to 72 hours' duration before entry. The numbers were too small to analyse according to time of onset of rash.
This study has shown that oral acyclovir may modify the course of acute herpes zoster and reduce pain. This benefit was most pronounced in patients who began treatment within 48 hours of the onset of rash. In addition, pain relief was particularly noticeable in those with the most severe pain. Acyclovir $800 \mathrm{mg}$ five times daily appears to be a suitable regimen, though better absorbed preparations should allow lower dosage regimens to be employed. It appears that a seven day course is preferable to a five day course of treatment. The effect of this regimen on postherpetic neuralgia is not known, but studies are continuing.

Collaborators in the study were: C D Care, research nurse, Lodge Moor Hospital, Sheffield 10; J A Innes, consultant, department of communicable and tropical diseases, and $\mathrm{P} \mathrm{H}$ Ogan, research nurse, East Birmingham Hospital, Bordesley Green East, Birmingham; E M Webb, research nurse, Southampton Eye Hospital, Southampton; and E A Hickmott, D A Jones, and A M Gilbert, Wellcome Research Laboratories, Beckenham, Kent.

\section{References}

1 Bean B, Braun C, Balfour HH. Acyclovir therapy for acute herpes zoster. Lancet 1982;ii:118-21.

2 Peterslund NA, Seyer-Hansen U, Ipsen J, Esmann V, Schonheyder H, Juhl H. Acyclovir in herpes zoster. Lancet 1981;ii:827-30.

3 McGill J, McDonald DR, Fall C, McKendrick GDW, Copplestone A. Intravenous acyclovir in acute herpes zoster infections. Fournal of Infection 1983;6:157-61.

4 McGill J. Topical acyclovir in herpes zoster ocular involvement. Br f Ophthalmol 1981;65:542-5.

5 Peterslund NA, Esmann V, Ipsen J, Christensen KD, Petersen CM. Oral and intravenous acyclovir are equally effective in herpes zoster. $\mathcal{F}$ Antimicrob Chemother 1984;14:185-9.

6 McKendrick MW, Care C, Burke C, Hickmott E, McKendrick GDW. Oral acyclovir in herpes zoster. F Antimicrob Chemother 1984;14:661-5.

7 Keczkes K, Basheer AM. Do corticosteroids prevent post-herpetic neuralgia? Br $\mathcal{f}$ Dermatol 1980;102:551-5.

8 Elliott FA. Treatment of herpes zoster with high doses of prednisone. Lancet 1964;ii:610-1.

(Accepted 24 September 1986)

\title{
Chemoprophylaxis with oral amoxycillin against bacterial endocarditis: When should second doses be administered after dentistry?
}

\author{
C R KUMANA， K K CHAU， P Y CHAU， M KOU， I LAUDER
}

\begin{abstract}
The adequacy of serum bactericidal activity after oral amoxycillin given as prophylaxis against infective endocarditis was studied using a double blind randomised protocol in healthy volunteers having dentistry. One hour before their procedure 38 patients received $3 \mathrm{~g}$ amoxycillin syrup and 12 received matching placebo. Venous blood samples were drawn before and one and nine hours after dosing and serum amoxycillin concentrations determined using a standard bioassay. Samples containing amoxycillin had inhibitory titres measured against two reference isolates of viridans streptococci known to have caused infective endocarditis. The susceptibility to amoxycillin of one strain was high
\end{abstract}

University of Hong Kong

C R KUMANA, BSC, FRCP, reader in medicine

$\mathrm{K}$ K CHAU, MDS, FRACDS, reader in oral surgery and oral medicine

P Y CHAU, MB, MRCPATH, reader in microbiology

$M$ KOU, SRN, senior research assistant, departments of medicine and oral surgery and oral medicine

I LAUDER, MSC, PHD, senior lecturer in statistics

Correspondence to: Dr C R Kumana, University Department of Medicine, Queen Mary Hospital, Hong Kong. and the other low, respective minimal bactericidal and inhibitory concentrations being 0.08 and $0.04 \mu \mathrm{mol} / 1(0.03$ and $0.015 \mu \mathrm{g} / \mathrm{ml})$ and 2.74 and $1.37 \mu \mathrm{mol} / 1$ ( 1 and $0.5 \mu \mathrm{g} / \mathrm{ml}$ ).

Amoxycillin was detected in only post-treatment samples of patients given the active drug. There were no significant correlations between one or nine hour drug concentrations and age or physical characteristics, nor was there any relation to preceding food consumption. Correlations between drug concentrations at one and nine hours were weak $(r=0.34 ; p<0.05)$, but between corresponding drug concentrations and serum inhibitory titres there were consistent correlations $(r=0.46-0.48 ; p<0.005)$. Against the low susceptibility reference isolate bactericidal amoxycillin concentrations were encountered in only 20 of the 38 nine hour samples (95\% confidence limits $34 \%$ and $66 \%$ ).

When repeat doses of amoxycillin are indicated after dentistry they should be given about four hours later, not eight hours later as commonly practised.

\section{Introduction}

A widely accepted and simple regimen of antimicrobial prophylaxis against bacterial endocarditis for patients with susceptible cardiovascular lesions having dentistry consists of giving amoxycillin $3 \mathrm{~g}$ 